\title{
DEVELOPING SPEAKING SECTION OF BUSINESS ENGLISH MATERIALS TO TEACH CULTURE IN INTEGRATED WAY
}

\author{
1Yasmin Farani; ${ }^{2}$ Karlina Karadila Yustisia \\ University of Merdeka Malang1,2 \\ Corresponding email: yasmin.farani@unmer.ac.id
}

\begin{abstract}
Teaching English Business skills does not merely teach the students to have administration and communication skills needed at the workplace for they will probably encounter and experience working together with people from different cultures and backgrounds as well. To minimize misunderstanding on those intercultural differences, they are expected not only to learn Business English skills but also gain basic knowledge of English culture through the course. This R\&D research is a descriptive qualitative research which is intended to develop the Speaking Section of the existing teaching materials of Business English skills. Under the name of ESP I subject, they are taught to the $4^{\text {th }}$-semester students of Diploma Three in English Program of University of Merdeka Malang as a compulsory subject. In this study, the primary instruments are the researchers themselves and the preliminary questionnaires used serve as the secondary instrument. All the analyzed data are in the form of printed data (questionnaire's results) and chosen videos taken from YouTube. The expected final results are in the form of written handouts consist of texts and links of selected videos appropriately related to the given topics. It is hoped that they are useful for the students as an alternative method to learn culture in an integrated way.
\end{abstract}

Keywords: Business English, culture, integrated teaching, qualitative research

\section{INTRODUCTION}

The Diploma Three in English Program is one of the diploma programs at University of Merdeka Malang (UNMER Malang) and since 2014 the Program has been applying the Kerangka Kualifikasi Nasional Indonesia (KKNI) Curriculum, which consists of 48 subjects with the total credits of 117 . In relation with this research on English for Specific Purposes, the following are the four subjects which correlate and support to each other in terms of contents: 
Developing Speaking Section of Business English Materials to Teach Culture...

Table 1. KKNI Curriculum

\begin{tabular}{lclcc}
\hline No. & Code & \multicolumn{1}{c}{ Subject } & Credit & Semester \\
\hline 1. & \multirow{2}{*}{630106} & $\begin{array}{l}\text { English for Specific Purposes I: Business } \\
\text { English }\end{array}$ & 2 & 4 \\
\hline 2. & 630322 & Cross Culture Understanding & 2 & 5 \\
\hline 3. & 630325 & Business Correspondence & 2 & 5 \\
\hline 4. & 630408 & Office Administration & 2 & 5 \\
\hline
\end{tabular}

English for Specific Purposes or ESP is the compulsory subject taught in two different semesters in a row; ESP I in the $4^{\text {th }}$ semester and ESP II in the $5^{\text {th }}$ semester. ESP I, which Business English becomes its concentration, is not a pre-requisite for the ESP II. This subject presents English skills, such as; reading, speaking and writing and is taught integratedly with American English culture. Moreover, teaching those skills of English should not be through isolation or teaching them separately. It should be done integratedly since teaching integrated skills apparently gives students chances to show themselves better in more meaningful tasks rather than they struggle hard in one skill (Farani, 2016). Since this subject is a two-credit subject, the total number of the meetings in one semester is 16, including the mid-term and final tests. It is a short period with a lot of things to be given to the students. That is why the topics must be carefully chosen to sufficiently cover the needs. Furthermore, in ESP I course it is intended to help the students to acquire English skills (reading, listening, speaking, and writing) in the contexts of Business English in the Intermediate Level. In this course, the activities cover: practicing business dialogs (speaking and listening sections), reading business texts (reading section) and writing business letters (writing section). Besides, it equips the students with commonly used of business vocabulary (vocabulary section).

As a vocational program, the Program always improves itself to cope with the market demands. Students must be prepared to be able to compete in the working world after they graduate. That is why its curriculum has to be continually restructured and the required skills subjects must become the priority. In order to reinforce the students to be ready to enter and accepted by the working world, especially which uses English instructions, the applicable subjects (required practices) must be taught more than theoretical ones with the percentage of 60:40.

Communicating in a foreign language is an essential requirement of the present job market and one can notice its constant pressure on the educational system that is expected to render professionals who can communicate effectively in a foreign language (mainly English) in their work settings. This means that knowledge of General English is implicit for undergraduates who further on need to be equipped with the ESP language 
skills so as to be able to meet the selection criteria of the job market. Companies are not so willing to invest in fresh graduates who, after completing their degrees, are expected to be ready to compete for jobs and enter the working life instantly. Marcu (2019) stated that graduates of college or university are expected to be able to communicate in foreign language, mainly English, in order to meet the selection of the job market since communicating using it is one of essential requirements of the present job market. That is why the knowledge of General English equipped with the ESP language skills is necessary to be given, even included in the curriculum.

Moreover, international business exchange is becoming increasingly frequent through globalization. The global activities are gradually being affected by the intercultural communication competence of today's business world. In that case, the demand to broaden the inculcation of cultural fluency in an educational program is needed, such as Business English. The main objective of Business English subject, according to Jingzi, Wenzhong, \& Dimond, (2016) is building an intercultural communication bridge between foreign cultures and native cultures and develop students' competence in cultural business English communication. Therefore, intercultural communication competence is a critical thing. In the intercultural exchange, the foreign learners will encounter great challenges; their native culture's communication practices and the way of thinking methods will always not be the same as the target culture, often lead to misunderstanding and disapproval. Communication competence (general pragmatic competence) is lacking without additional intercultural communication knowledge (Jingzi et al., 2016).

As for the culture, it is considered essential to place cultural activities in ESP. Zaghar (2016) believes that an ESP classroom is suitable room for initiating an interchange to promote the students to learn better by implementing useful tasks than by doing a monotonous activity and relying on the teacher as the main source of knowledge. He also set two principal aspects to develop an advanced level of cultural competence and awareness. First, in terms of cultural knowledge which implies the understanding of cultural distinction. Second, in terms of cultural skills which signifies the ability to act and behave in appropriate way in various cultures. These capabilities which include common comprehension, acceptance, tolerance, and dealing with the contradictory situation

Regarding those above references, it is obvious that including cultural activities in the ESP subject is an appropriate choice. First, they do not only imply the understanding of cultural distinction (cultural knowledge) but also signify the ability to act and behave in appropriate way in various cultures (cultural skills). Second, using intercultural materials in learning English as a second language is very important, even essential. Besides they would make 
the students familiar with the native speakers' culture and customs. This will definitely also help them increase their cultural awareness. According to Crawford-Lange and Lange (1987), language and culture are like two peas in a pod; they are inseparable. Culture must be included in language study. Students of English must be taught culture as well for it is in the act of becoming that is why it should be taught as process of the learning.

In the attempt of always improving the existing Business English materials, this current research is done. Verily, one of the authors previously had conducted a couple similar research in Business English; ESP Business English: The Proposed Students' Workbook Used for Teaching Bahasa Inggris Bisnis at D3 Accounting of Economics \& Business Faculty at Universitas Merdeka Malang (Farani, 2017) and Business English Subject: Developed Worksheets for Students of D3 Banking and Finance Program Universitas Merdeka Malang (Farani, 2017). However, it has different focuses. While the other two focus on English skills and vocabulary, the latest one focuses on English skills, especially speaking and culture.

The latest research on Business English is intended to develop the speaking section of the existing teaching materials of Business English skills. Since the researchers considered students needed to be more exposure toward the culture of the target language. The disclosure in the classroom is not only through reading the cultural informative texts, but also watching and listening to the provided videos which are related to the discussed topics. egarding the use of technology for language learning, Larsen-Freeman and Anderson (2011) stated there are two major ways to think about technology regarding language learning; that is technology as providing, first, teaching resources and second, enhanced learning experience. Furthermore, they also introduced four terms that can be used as teaching resource and they are in the forms of a blog, a social networking site (e.g. Facebook), YouTube, Wiki and electronic text corpus (a collection of authentic spoken and written texts). Thus, it is apparent that technology, in this case they are internet and videos, is relevant to be used to support the language learning process.

\section{METHODS}

This research is a qualitative one. The major difference between quantitative and qualitative approaches is in the idea of quantity and quality. Berg quoted Dabbs (2001, 2-3): that the quality is essential to the nature of things and its research thus refers to the meanings, concepts, definitions, characteristics, metaphors, symbols, and description of things. Meanwhile, the quantity is elementally an amount of something and its research refers to counts and measures of things. As it a qualitative, the researchers used questionnaires to obtain data. Gall, Gall and Borg, $(2003,223)$ stated that although questionnaire and interviews are both can be used in either type of research (qualitative and 
quantitative), however they are more commonly used in qualitative one. They added that because its standardized, highly structured design, questionnaire is compatible with qualitative one. Latief $(2010,101)$ stated that R\&D research is a qualitative research and it is commonly conducted to produce a set of teaching learning apparatus, among others are syllabus, teaching materials, module, and students' workbook.

\section{Participants}

Both of the researchers were lecturers of the ESP I subject. They thought that existing Business English materials; especially the speaking section, needed an improvement. In order to make the research more effective, they used their own classes. That is why the participants of this research are $4^{\text {th-semester }}$ students who were currently studying the ESP I subject and their total numbers are 39 people.

\section{Instruments}

This research is aimed to develop the speaking section of the existing teaching materials; especially the culture focus section. That is why it has two kinds of instruments namely, primary and secondary instruments. In this research, the human investigators or the primary instruments are the researchers themselves who did library research, conduct an observation, distribute and recap the results of the preliminary questionnaires. According to Bogdan and Biklen $(2007,5)$, qualitative research is descriptive so that the collected data are in the form of words or pictures rather than numbers. Those data among others are interview transcripts, field notes, photographs, and videotapes. In this research, the collected data are descriptive data (printed data) which was taken mostly from the results of the preliminary questionnaires. Therefore, the secondary instrument used was those preliminary questionnaires themselves. They are subjective needs questionnaires which consist of 8 questions divided into two parts; four questions concerning ESP I subject (A section) and four questions concerning with the culture focus section (B section). The list of the questions can be seen in Table 2 below. They were distributed to the $4^{\text {th }}$-semester students who were currently studying the ESP I subject. They were given at the end of the semester with the purpose of getting students' personal responses after they took the subject for the whole semester (14 meetings). As for the data to be analyzed, all of them are in the form of printed data and selected videos taken from YouTube. The reasons why the researchers chose videos and YouTube as the main source are discussed in detail in Findings and Discussion.

Table 2. Preliminary Questionnaire 


\begin{tabular}{cl}
\hline No. & \multicolumn{1}{c}{ QUESTIONS } \\
\hline A & ESP 1: Business English \\
\hline 1 & How did you find learning ESP 1 subject in general? \\
\hline 2 & $\begin{array}{l}\text { How did you find learning an integrated subject \& skills, e.g., Business } \\
\text { English \& reading/speaking/ writing? }\end{array}$ \\
\hline 3 & $\begin{array}{l}\text { How did you find studying the content materials of Business English } \\
\text { subjects, e.g., writing business letters and planning a business trip? }\end{array}$ \\
\hline 4 & How did you find the given assignments and tasks? \\
\hline B & Culture Focus: \\
\hline 5 & How did you find learning the integrated speaking skill and culture? \\
\hline 6 & How did you find learning the Culture Focus section? \\
\hline 7 & How did you find the content of the Culture Focus section? \\
\hline 8 & How will you find it if there's a video in relation to the cultural topic?
\end{tabular}

\section{Data Analysis Procedures}

Furthermore, as it is to develop the cultural focus of the speaking section of the existing materials, the researchers applied the framework components proposed by Grave $(1996,13)$, as seen in Table 3 below. There are other frameworks to develop teaching materials which proposed by Brown (2007, 148-161), however the researchers considered that Grave's was the appropriate one.

Table 3. Grave's Framework Components

\begin{tabular}{ll}
\hline Components & Contents \\
\hline Need Assessments/Analysis & Objective and Subjective Needs \\
\hline Determining Goals and Objectives & Goals and Objectives \\
\hline Conceptualizing Content & $\begin{array}{l}\text { Language components Language } \\
\text { functions Language skills Genre/Texts, } \\
\text { etc. }\end{array}$ \\
\hline Selecting and Developing Materials & $\begin{array}{l}\text { Selecting materials Teaching-learning } \\
\text { and Activities }\end{array}$ \\
$\begin{array}{l}\text { Techniques } \\
\text { Organizing Content and Activities }\end{array}$ & Lesson Level and Course Level \\
\hline Evaluation & Students' assessment \\
\hline Consideration of Resource and & - \\
Constraints & \\
\hline
\end{tabular}

The researchers, however, did not apply all those components, only some of them, and they did not thoroughly discuss Grave's contents. The culture focus is a part of the speaking section of each unit (see Table 4) that is why it does not require all the components of Grave's framework. The three mostly used components are as follows: Need Assessment/Analysis to 
develop the preliminary questionnaires, Selecting and Developing Materials and Activities, and Determining Goals and Objectives.

\section{FINDINGS}

The existing teaching materials of Business English cover four skills and a language component. They are reading, speaking, writing, and listeningwhich is not done separately, but integrated along with reading and speaking-and, vocabulary. Each skill presents exercises and assignments at the intermediate level, which can be done individually or in groups/pairs. In the reading section, apart from the given texts, students are required to do comprehension exercises. The given texts cover topics that are related to business. In the speaking section, they are required to practice the dialogs which are related to the discussed topics in each unit. Apart from this, they learn English culture as well. In the writing section, they are required to study kinds, styles, and components of formal letters. Besides, they are also required to practice writing business letters such as inquiry letter, order letter and application letters. Regarding the listening skill, there are no separate exercises for this skill; it is done in integrated way with reading and speaking skills (listening while reading the texts and practicing the dialogs). The last, in the vocabulary section, they learn words and phrases in business English by doing the given exercises.

As international business courses, designing this business English course needed multidisciplinary tasks although it is not that complex as ones. However, it has to deal with issues and functions; such as management and marketing, and in this business English course are in the forms of reading passages and vocabulary. Furthermore, as for the teaching materials, according to Aggarwal and Zhan (2018), they should challenge and motivate the students to learn and the course, among others, would include class and take-home project. As for the take-home project, the author included planning a business trip project in the lesson plan of the course. For this study, however, the researchers focus on the speaking section which apparently is not discussed in all units. It appears only in the following units: 2, 4, 7, 9, 11 and 13 with the following topics: Business Introduction (2), Around the Office (4), On the Phone (7), Making Reservation (9), Getting Around (11) and Making Order (13). In each unit, the speaking section consists of dialogues, practices, and culture focus. By adding a video or two in each of those units, the researchers expected that students do not only get more understanding of the discussed topics but improve their listening skills as well. From the short texts, the students get a brief and useful explanation about culture related to the discussed topics while the videos clearly visualize what the texts talk about and complete the information that the students have learned. The following Table 4 describes the details of each unit of the developed materials. 
Table: 4 The Developed Materials

\begin{tabular}{|c|c|c|c|}
\hline Unit & Topic & Speaking Skill & Cultural Focus \\
\hline \multirow[t]{2}{*}{2} & Business Introduction & $\begin{array}{l}\text { Dialog: business } \\
\text { introduction }\end{array}$ & $\begin{array}{l}\text { Business cards, Shaking } \\
\text { hands, and Business } \\
\text { clothing }\end{array}$ \\
\hline & & & $\begin{array}{l}\text { Videos: exchanging } \\
\text { business cards \& } \\
\text { shaking hands }\end{array}$ \\
\hline \multirow[t]{2}{*}{4} & Around the Office & $\begin{array}{l}\text { Dialog: around the } \\
\text { office }\end{array}$ & $\begin{array}{l}\text { Informality } t \text { the office, } \\
\text { Employee break rooms } \\
\text { \& cafeterias, and After } \\
\text { work }\end{array}$ \\
\hline & & & $\begin{array}{l}\text { Video: conversation at } \\
\text { the employee break } \\
\text { room }\end{array}$ \\
\hline \multirow[t]{2}{*}{7} & On the Phone & Dialog: on the phone & $\begin{array}{l}\text { How to use the } \\
\text { telephone }\end{array}$ \\
\hline & & & $\begin{array}{l}\text { Video: etiquette on the } \\
\text { telephone }\end{array}$ \\
\hline \multirow[t]{2}{*}{9} & Making Reservation & $\begin{array}{l}\text { Dialog: making } \\
\text { reservation (via } \\
\text { telephone) }\end{array}$ & $\begin{array}{l}\text { Advice for using hotels } \\
\text { and Credit card } \\
\text { transaction by } \\
\text { telephone }\end{array}$ \\
\hline & & & $\begin{array}{l}\text { Video: making hotel } \\
\text { reservation by phone }\end{array}$ \\
\hline \multirow[t]{2}{*}{11} & Getting Around & Dialog: getting around & Asking the way \\
\hline & & & $\begin{array}{l}\text { Video: how to politely } \\
\text { ask the way }\end{array}$ \\
\hline \multirow[t]{2}{*}{13} & Making Order & $\begin{array}{l}\text { Dialog: making order } \\
\text { (via telephone) }\end{array}$ & $\begin{array}{l}\text { Saying thank you, Sales } \\
\text { tax, Credit cards and } \\
\text { Personal checks }\end{array}$ \\
\hline & & & $\begin{array}{l}\text { Video: making order } \\
\text { by phone }\end{array}$ \\
\hline
\end{tabular}

The following are two examples of the proposed materials; the Culture Focus section taken from Unit 2 Business Introduction and Unit 7 On the Phone. Both have been added with the selected videos related to the discussed 
topic. Below is taken from Unit 2; that is exchanging business cards, shaking hands (formal business introduction) and business clothing.

\section{UNIT 2: BUSINESS INTRODUCTION \\ Activity 3: Culture Focus \\ Business Cards}

Among Americans, exchanging business cards is not a formality. American business people generally do not exchange business cards with each other during an introduction. They may exchange business cards at the end of a meeting if they want to keep in contact.

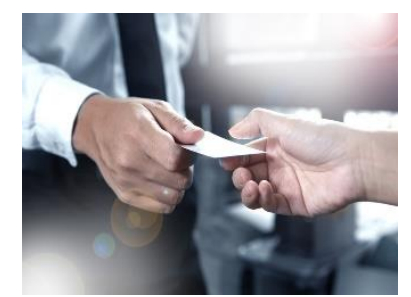

Check out this video!

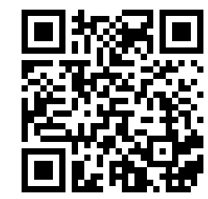

Figure of exchanging business cards

Assignment: while watching the video, jot important information down. Later discuss them with the class.

\section{Business Clothing}

Business clothing in America is often more casual than in other countries.

However, American businessmen usually wear suits:

a. when they are interviewing for a new job.

b. when they meet other business people for the first time.

c. when they meet with important clients.

d. when they attend an important event (e.g. a reception, a conference, a speech, etc.)

Professional businesswomen in the US usually wear:

a. skirts and blouses (often with a jacket).

b. dresses (sometimes with jacket).

c. suits.

Both men and women usually dress more formally as their job levels increase.

The second example, taken from Unit 7, gives students not only the tips on how to use the telephone but it gives vivid etiquette (Do's and Don'ts) on using the phone as well, as seen in the video. 


\section{UNIT 7: ON THE PHONE}

\section{Activity 3: Culture Focus}

How to Use the Telephone

1. Mute or turn off the television or radio or music (background noise) before attempting to use the phone.

2. Use an approved company greeting when answering a business call. Do not just say "Hello" as some callers will consider this unprofessional.

3. Be sure to state the purpose of the call early in the conversation, and thank the other person before you complete the call.

4. Have a pen and paper handy, or be ready at the keyboard to write down or type any addresses, phone numbers, dates, or other important facts that might be discussed during the call.

5. If the person does not answer by five rings, assume that they are talking on the phone to another caller via call waiting. Excess ringing is annoying while attempting to talk to another person.

6. Do not throw the telephone, drop it, or allow it to become dislodged and fall to the floor - the noise can be very rude to the person on the other end.

7. Do not chew gum, eat food, drink, or go to the bathroom while on the phone.

8. Make sure that background noise is kept to a minimum during the call.

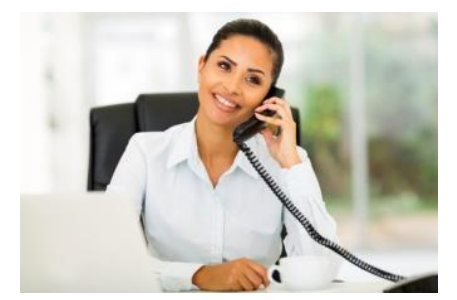

Check out this video!

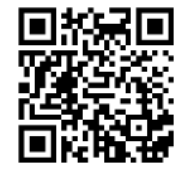

Do's and Don'ts on the Phone Etiquette

Assignment: while watching the video, jot important information down. Later discuss them with the class.

\section{DISCUSSION}

As mentioned in the previous sections, the Method and the Findings, to develop teaching materials, the researchers used three Grave's framework components; Need Assessment/Analysis, Selecting and Developing Materials and Activities, and Determining Goals and Objectives. The discussions of each of them are as follows.

Need Assessment/Analysis. To complete the development of the teaching materials, ESP (English for Specific Purposes) is the right choice rather than EAP (English for Academic Purposes) for its purposes are concerned with the learner's needs (Richards, 2001). Thus, before developing the teaching materials, the researchers had to know learners' or students' needs first by developing the preliminary questionnaires. After they were 
ready, the researchers distributed and recapped the results of the preliminary questionnaires given to the $4^{\text {th }}$ semester who were currently taking ESP I subject and there were 38 students participated in the survey of the study. Those secondary instruments or preliminary questionnaires are subjective needs questionnaires which consist of 8 questions and are divided into two parts; four questions in the A section and the other four in the B sections. The reason why the researchers used subjective needs questionnaire is that they are mainly focus on needs as seen through the eyes of the learners themselves. Learners' needs are primarily. These are maybe more difficult to gather, however, they are sought through, among others, interviews, questionnaires, and observations (Brown, 2007).

The A section aims to examine the students' responses towards the overall content material of the ESP I: Business English subject. The B section shows students' attitudes towards the culture focus taught integratedly in the related subject. The results show that $75.78 \%$ of the students stated that learning an integrated subjects and skills in Business English class were useful, $77.36 \%$ students stated that the culture content of the subject was very useful and $78.42 \%$ students stated that it was very useful to add videos to support the understanding of the culture focus section. This means that they know and realize the importance of learning culture while learning language skills. Language and culture are important to each other; they are part of each other. They are intricately interwoven to each other so that we cannot teach them separately without losing the significance of either language or culture (Brown, 2007).

Determining Goals and Objectives. Next step, after completing the need assessment/analysis step, the researchers determined the goals and objectives of developing the teaching materials. While the objectives are to explore varying communication styles within multicultural groups and to learn the way to deal with these varying styles, the outcome or goal is expected the learners to develop a more sensitive approach to the behavior of diverse people in multicultural environments. Different obvious behaviors will be proposed. Another principal outcome or goal is that students should grasp how these characteristics and behaviors can enhance good relationships, tolerance, and mutual understanding in intercultural situations.

Selecting and Developing Materials. As it is discussed in the Method section, the researchers applied Grave's framework of components although they did not use all the 7 components proposed by Grave; only took three compenents which are related to the process of developing the materials. In the third step, before developing the materials, the researchers did the selection step by browsing and choosing appropriate videos that are going to be used in the speaking section of the Business English course. There are hundreds even thousands of videos provided by YouTube, that is why the 
researchers decided to set some criteria regarding to this matter. To be more precise, there are five considerations should be taken into account in choosing those videos on YouTube, namely: reliable source, language consideration, length of the video, audiovisual quality and content. First, reliable sources are important since videos on YouTube are possibly made and uploaded by certain institutions or organizations and even individuals. Wherefore, we preferably chose the reliable ones. Second, the language used by native speakers should not be too difficult for EFL students to comprehend. The video sources should speak clearly with good pronunciation and are less rapid. Third, the length of the video should not be either too short or too long. The researchers decided to download videos with approximately 3-4 minutes length of time. Next, the audiovisual quality should be clear and in high quality. The last, the content presented has to be matched with the topics discussed in each of the units which include the speaking section.

Concerning with the use of videos in the language classroom, Wang (2015) indicates there are three aims of teaching English using video materials; first, to facilitate the language skills development of the EFL students which carries a lot of information, to get the attention focus on the material, and to improve the comprehensiveness of their linguistic competence. Second, to cultivate students' competence in intercultural information. By using video in the classroom, the students can also learn about the culture of the English used by native speakers. Thus, their communicative competence develops. Third, to promote students' aesthetic values and ability through artistic principles of the English video. The students are expected to have aesthetic impressions of the video which can encourage them to have deep thinking and thus lead to critical thinking. The given video included in the culture content on the speaking section of the ESP I subject is matched with the first and the second aims proposed by Wang (2015) above. They are matched with the objective of the course as well, as it is intended to help the students to acquire English skills in the contexts of Business English. Furthermore, Smaldino, Lowther, and Russel (2008, p. 411-413) referred to ASSURE (Analyze, State, Select, Utilize, Require, Evaluate) model regarding with the benefits and limitations of using video in learning process: 1) benefits; moving (bergerak), process (proses), free risk observation (pengamatan yang bebas resiko), being dramatized (dramatisasi), skills learning (pembelajaran keterampilan), affective learning (pembelajaran afektif), problem solving (penyelesaian masalah), cultural understanding (pemahaman budaya) and bonding (membentuk kebersamaan), and 2) limitations; steady speed (kecepatan yang tetap), talking people (orangorang yang berbicara), silent phenomenon (fenomena yang diam), misintrepreting (salah penafsiran) and abstract and nonvisual learning (pengajaran abstrak dan nonvisual). In summary, the use of the advanced technology does fully support the process of teaching learning, however, there are still limitations 
that should be considered. The use of technology, in this case is internet, is inseparable from teaching and learning process in the classrooms. Still, the teacher should be wiser and give careful thought and consideration in using it.

Once the selection step is completed, the researchers directly continued to the developing materials step. They developed and improved the speaking section, especially its culture focus section. The old materials did not include videos there, so in the new ones, the researcher added selected videos related to the discussed topics (see Table 4). It has positive responses from the students for the results of the preliminary questionnaire showed they agreed that videos were added in the teaching-learning materials by ticking the very useful option.

The researchers assume that through integrating an intercultural approach, ESP teachers can help their learners activate their intercultural awareness, improve their language abilities most importantly and acquire a proper management tool of their very own behaviors. One of the strategies to contributing intercultural awareness in the classroom is by providing a reallife situation or occasion that the learner might face in the real workplace. According to Zaghar (2016), throughout many years and before including the new intercultural technique within the teaching of ESP to students, classroom observation shows that ESP teachers and practitioners do include nothing much or no cultural components of their courses. Therefore, the classes generally tend to function in the limitations of a monotonous routine and are teacher-driven.

As international business courses, designing this business English course needed multidisciplinary tasks although it is not that complex as ones. However, it has to deal with issues and functions; such as management and marketing, and in this business English course are in the forms of reading passages and vocabulary. Furthermore, as for the teaching materials, according to Aggarwal and Zhan (2018), they should challenge and motivate the students to learn and the course, among others, would include class and take-home project. As for the take-home project, the author included planning a business trip project in the lesson plan of the course.

\section{CONCLUSION AND SUGGESTION}

The results of this $R \& D$ research are proposed teaching materials for teaching ESP I subject which concentrates on Business English. The teaching materials include four language skills which are done integratedly; such as reading and listening, speaking and listening. According to Brown (2007, 285), teaching integration skills provides the teacher with a great deal of flexibility in creating interesting, motivating lessons. This means, by teaching integrated skills, the teacher gains beneficial impact as well; he or she has flexibility in 
creating interesting, motivating lessons. This has been proved by the researchers themselves by conducting this research. They developed and improved the speaking and cultural focus sections of the existing teaching materials. As for the cultural focus section, which is integrated with speaking section, it gives the students additional information about culture related to the discussed topic and it increases their awareness of the target culture and customs. As for the chosen videos downloaded from YouTube, apart from giving cultural exposures, they obviously give the students the opportunity to practice more their listening skill as well. In conclusion, the objective to integratedly teach language skills, especially speaking skill, and culture is fulfilled.

Moreover, the researchers realized that there were time limitations (only 14 effective meetings required) and many things to cover. Therefore, first, they do hope that the students can learn more in the next semester or the 5th semester on CCU subject (for culture understanding), Business Correspondence (for writing business letters) and Office Administration subject (for business administration). Second, it is hoped that researchers, who are working on a similar topic, can use this study as a reference. Third, they also hope that other researches will possibly be interested in developing materials for EOP or English for Occupational Purposes, for example; English for Secretary and English for Administrator since it is still hardly conducted.

\section{REFERENCES}

Aggarwal, R. \& Zhan, F. (2018). Course Design Considerations in International Business Education, Journal of Teaching in International Business, 29:4, 267-271, DOI: 10.1080/08975930.2018.1560676

Ary, D. et.al. (2002). Introduction to Research in Education., $6^{\text {th }}$ ed.,. Belmonth, CA: Wadsworth Group/Thomson Learning.

Berg, B.L. (2001). Qualitative Research Methods for Social Sciences. Needham Heights, MA: Pearson Education Company.

Bogdan, R.C. and Biklen, S.K. (2007). Qualitative Research for Education: An Introduction to Theories and Methods. Pearson Education, Inc.

Brown, H. D. (2007). Teaching by Principles: An Interactive Approach to Language Pedagogy. New York: Pearson Education, Inc.

Crawford-Lange, L.M. \& Lange, D.L. (1987). Integrating language and culture: How to do it, Theory into Practice, 26:4, 258-266, DOI: 10.1080/0040584870954328

Gall, M.D., Gall, J.P. and Borg, W.R. (2003). Educational Research. Seventh Edition. Boston: Pearson Education, Inc.

Grave, K. (1996). A Framework of Course Development Process in Grave, K. (Ed.), Teachers as Course Developers, New York, NY: Cambridge University Press. 
Farani, Y. (2016). The Proposed Culturally Rich Instructional Materials of Integrated Oral Course for The Fifth Semester Students of D3 English Program at University of Merdeka Malang. EnJourMe (English Journal of Merdeka): Culture, Language, and Teaching of English, 1(1), 1-16. https:/ / doi.org/10.26905/enjourme.v1i1.277

Farani, Y. (2017). ESP Business English: The Proposed Students' Workbook Used for Teaching Bahasa Inggris Bisnis at D3 Accounting of Economics \& Bussiness Faculty at UNMER Malang. EnJourMe (English Journal of Merdeka): Culture, Language, and Teaching of English, 2(1), 61-71. https://doi.org/10.26905/enjourme.v2i1.631

Jingzi, D., Wenzhong, Z., \& Dimond, E. E. (2016). The Integration of Intercultural Business Communication Training and Business English Teaching. English Language Teaching, 9(2), 77-83. https://doi.org/10.5539/elt.v9n2p77

Wang, Z. (2015). An Analysis on the Use of Video Materials in College English Teaching in China. International Journal of English Language Teaching, 2(1), 23-28. https://doi.org/10.5430/ijelt.v2n1p23 